as the last few months have proved, have fallen a sacrifice to their conscientious discharge of duty, and the wonder is, that the mortality amongst medical officers has not been considerably higher. Surely this is a class which demands better consideration than it has hitherto received.

It is not necessary, neither is it my intention, to continue these reports, because they require more time and labour than a medical officer can well afford.

In conclusion, I earnestly call upon every medical practitioner, in what sphere soever he may be placed, to aid, by every means in his power, in obtaining that proper and reasonable remuneration which is justly due for important public services of this nature.

Frederick SMith Garlick

Medical Officer for the Township of Halifax

\section{PETITION OF THE MEDICAL OFFICERS OF THE HALIFAX UNION TO THE POOR-LAW COM- MISSIONERS.}

\section{(COPY.)}

The Humble Petition of the undersigned Medical Offcers of the Halifax Union,

Sвететн,-That your petitioners are labouring under heavy responsibilities in the administration of medical relief to the poor; that their duties are very arduous, and that the stipends they reccive are so extremely inadequate as to justify them in making an earnest appeal to you, in the hope that you may be induced to investigate the subject of medical remuneration and render them that justice which the extent and importance of their services seem to them to merit.

That your petitioners have already laid this matter before the board of guardians of the Halifax Union, but that body has resolutely refused to revise or in any way alter the salaries which have hitherto been paid to their medical officers ; and therefore your petitioners have no other alternative than humbly to represent their case to you, praying that you will condescend to give it that calm consideration which they are unable to obtain from the board of guardians of the Halifax Union.

Your petitioners deeply regret that their firm but temperate statements to the board of guardians were not met in a corresponding spirit, that they have had to endure much painful and illiberal abuse; that certain documents, prepared as evidence of the large amount of labour performed, were not permitted to be examined or read, thereby affording convincing proof that justice from the board was not to be obtained.

Your petitioners, in conclusion, humbly pray that the members of a learned and truly benevolent profession may not, in requital of ardnous duties, be subjected any longer to unmerited reproach and totally inadequate remuneration, but that they may receive at your hands that consideration and support which are preëminently due for the important and responsible offices they are hourly called upon to discharge.

And your petitioners will ever pray.

W. Brook, Stainland; R. Atkinson, Ovenden; F. S. Garlick, Halifax; R. McLachlan, Shelf; W. Elliott, Sowerby-bridge; E. Aked, Luddenden; J. Robinson, Rippendon; T. Robertshaw, Sowerby bridge; C. H. Macaulay, Rastrick ; T. Harrison, Halifax; J. Hiley, Elland.

This petition was forwarded on the 6th September, 1847, signed by all the medical officers of the Union, with the exception of two.

\section{THE POOR-LAW SURGEONS.}

\section{To the Editor of The Lancet.}

Sin,- I am glad to find that Union medical officers are at last beginning to agitate for something like justice; at the same time, I seriously fear that but little good will be achieved until the profession is more united, until as a body we are resolved to repudiate the disgraceful terms upon which an immense number of highly respectable medical men have been so long compelled to be mixed up with penurious boards of guardians. I am decidedly of opinion, that a fair and just remuneration must long since have been conceded to the Union surgeons, for the many arduous and important duties which they are daily, nay hourly, called upon to perform, but for this lamentable fact, which $I$ repeat-the profession is not united. "Hinc illæ lachrymæ." Were it otherwise, " that portion of it holding office in poor-law unions may soon be raised from the Slough of Despond into which it has fallen." When an honourable-minded man $-\mathrm{a}$ man having a due regard for the honour and dignity of his noble and beneficent calling,--has declined to accept an appointment under the Poor-law amendment Act, on terms which he poignantly felt to be disreputable to him, what has been the result? Advertisements have been inserted in all the local prints; a host of candidates are induced to come forward, and the person elected to fill the vacancy, not only attends the sick poor, but the guardians themselves, and, through their recommendation, their friends also; the other surgeon is left in possession of the pleasing alternative of remaining without practice, sneered at as one influenced by mercenary motives, or he is necessitated to betake himself elsewhere. Sincerely thanking you for many spirited exertions in behalf of the numerous medical men connected with the poor-law, which merit all praise, and fervently hoping that the deplorable state of things to which $I$ have adverted will soon cease to exist,-I am, your constant reader,

Downington, Oct. $18+7$.

A Countrit Surgeon.

\section{MEDICAL REGISTRATION.}

THE efficient organization of the medical profession ought to form no secondary object with the governments of civilized communities. We attribute no small amount of the enormous sanitary evils under which this country labours, to the want of anything like organic union amongst the members of the medical profession, and to the inefficiency of existing medical corporations. It was on this account that we drew attention to the question of medical reform, and adrocated Mr. Wakley's Registration Bill as likely to produce good results. But whilst in this country we were contending for first principles, and seeking for a small amount of beneficial change, the Chamber of Deputies in France was occupied with discussing a much more complete and substantial measure than any that has been proposed in Great Britain. This has arisen from the fact, that in that country, hospitals and corporations have not been left to their own mismanagement and corruption. Long ago did France cast away the reproach of making her charitable institutions spheres for increasing the wealth and the patronage of a few ignorant and selfish surgeons and physicians. It is on this account that Paris has for many years been justly regarded as the first medical school in the world. Her Larreys, Dupuytrens, Laennecs, and Louis, have never been the nominees of an irresponsible few, but have obtained their commanding positions through industry and merit alone. In France there are not seventeen corporations to consult at each step of medical reform, each with its own paltry end and selfish purpose to serve in opposing the public good.

For some time past, the attention of the Minister of Instruction in France has been directed to improvements needed in the present state of medical law, and on his representation to the King, a commission, consisting of the most eminent medical men in France, was appointed, for the purpose of deliberating upon the alterations required. The object of this commission was to decide "upon interests affecting the public health, the right of all classes to an equal partition of medical assistance, the most efficient guarantees of medical knowledge, the conditions of the studies, and the sacrifices imposed upon a whole class, of the youth of France; the advantages which may accrue to families and towns; the rights attached to professorships; but, above all, the progress and development of science; for this interest must predominate above all others." Such was the object set before the commission of medical men in France, the report of a committee appointed by which was the subject of discussion in the Chamber of Deputies during its last session. Some may inquire here whether such a commission of medical men might not have been appointed in England? But from whence, we ask, would the. materials for such a commission have been found? Unfortunately, the most distinguished medical men in England are all more or less connected with some of her corporations, and it is the class interests and class prejudices of these bodies that have kept England behind every other country of Europe in her medical organization. At this moment, instead of assisting Mr. WAKLEY to render his Bill for the next session more efficient and valuable, the three corporations of London, the Colleges of Physicians and Surgeons and the Apothecaries' Society, are using every effort to frustrate its becoming law. That their efforts will be successful we doubt, especially since the publication of the evidence taken before the select committee of the House of Commons appointed to inquire into the registration of legally qualified practitioners in medicine and surgery. We shall shortly refer to the evidence against that Bill, for what we think is most conclusive evidence in favour of the principles on which it is based.-Daily News. 